\title{
KETERAMPILAN BERFIKIR (MINDSKILLS) DALAM PERSPEKTIF PENGUBAHAN PERILAKU KONSELING REALITA
}

\author{
Abi Fa'izzarahman Prabawa ${ }^{1}$, Eni Rindi Antika ${ }^{2}$ \\ ${ }^{1}$ Institut Agama Islam Negeri Salatiga \\ ${ }^{2}$ Universitas Negeri Semarang
}

\section{Informasi Artikel \\ Histori Artikel:}

Diterima 3 Juni 2021

Revisi 10 Juni 2021

Disetujui 15 Juni 2021

\section{Penulis Korespondensi:}

Abi F. Prabawa,

Email: abibkum@gmail.com

\begin{abstract}
ABSTRAK
Konseling realita dan mindskills memiliki pandangan yang sama bahwa pusat kontrol perilaku manusia berpusat di otak. Penelitian ini menggunakan metode studi kepustakaan. Tujuan dari penelitian ini adalah untuk menjelaskan keterampilan berfikir (mindskills) dalam perspektif pengubahan perilaku konseling realita. Perilaku total dalam konseling realita terdiri dari empat komponen, yakni: pikiran, tindakan, perasaan, dan fisiologis. Pikiran dan tindakan dapat secara langsung dikendalikan oleh manusia. Perasaan dan fisiologis menjadi dampak dari pengendalian pikiran dan tindakan. Oleh karenanya untuk membantu mengendalikan pikiran dan tindakan diperlukan implementasi mindskills. Mindskills pengharapan dan persepsi digunakan untuk mengelola wants secara realistis, presisi, dan penuh dengan pertimbangan dalam memutuskan keinginan sesuai kebutuhan. Mindskills citra visual membantu menggambarkan kebutuhan yang tepat. Mindskills peraturan dan penjelasan membantu agar tindakan yang dilakukan lebih luwes, sesuai kondisi, realistis, dan rasional. Mindskills wicara diri membantu mengkondisikan perasaan dan fisiologis.

Kata kunci: Mindskills; konseling realita; pengubahan perilaku
\end{abstract}

\section{PENDAHULUAN}

Bimbingan dan konseling (BK) merupakan bagian integral dari keutuhan layanan pendidikan di sekolah. Kesuksesan siswa dalam menempuh pendidikan di sekolah tidak terlepas dari peran kepala sekolah, guru, dan konselor/guru BK. Bimbingan dan konseling memiliki peran penting dalam pengembangan aspek psikologis yang optimal dan perubahan perilaku siswa menuju kemandirian (Kemdikbud, 2016).

Bentuk layanan yang menjadi inti dari kiprah BK di sekolah adalah layanan konseling. Bahkan, konseling disebut sebagai jantung hatinya dari layanan BK di sekolah (Rigg, 1941; Prayitno \& Amti, 2015). Begitu vitalnya peran konseling di sekolah, menuntut kualitas dan profesionalitas dari seorang konselor selaku pengemban tugas 
mulia tersebut. Kualitas dan profesionalitas konselor dalam konseling akan meningkatkan kepercayaan konseli terhadap layanan konseling dan meningkatkan peluang keberhasilan konseling (Egan, 2010; Prabawa \& Antika, 2015, Antika, 2017). Terdapat tiga keterampilan yang harus dikuasai oleh konselor dalam melaksanakan konseling, yaitu: keterampilan intervensi, keterampilan komunikasi, dan keterampilan berfikir (mindskills) (Joni, 2008; Mulawarman \& Antika, 2020).

Mindskills merupakan keterampilan berfikir akan berimplikasi pada aspek kognitif, afektif, dan tindakan konselor ketika melaksanakan konseling (Mulawarman \& Antika, 2020). Melalui mindskills setiap ucapan, perasaan, dan tindakan konselor benar-benar dicermati dan difikirkan konsekuensi-konsekuensinya terhadap keberhasilan konseling. Azmi (2015) menambahkan bahwa mindskills akan mengiringi konselor dalam melaksanakan setiap langkah proses konseling dan membantu dalam pengambilan suatu keputusan dalam konseling.

Beberapa hasil riset berkaitan dengan mindskills di Indonesia dilakukan untuk menemukan kontribusi penting mindskills dalam konseling. Adapun beberapa riset tentang mindskills diantranya: proses audit dan penerapan mindskills para calon konselor (Hidayah, 2009; Hidayah, 2012); proses metakognisi konselor sekolah (Radjah, 2016); pengembangan produk panduan mindskills (Azmi, 2015); pengembangan produk bahan ajar mindskills (Purwaningrum, 2013); proses internalisasi mindskills dalam matakuliah keterampilan dasar komunikasi (Antika, 2017); hubungan motif pribadi dan mindskills (Mulawarman, dkk., 2017).

Beberapa riset tersebut memberikan gambaran bahwa mindskills memiliki dampak yang baik atas kontrol terhadap fikiran, perasaan, dan tindakan dalam pelaksanaan konseling. Salah satu pendekatan konseling yang fokus pada aspek pikiran dan tindakan dalam proses pengubahan perilaku adalah konseling realita. Melalui artikel ini akan dikaji bagaimana peran mindskills dari perspektif pengubahan perilaku dalam konseling realita.

\section{METODE}

Penelitian ini menggunakan metode penelitian studi kepustakaan (library research). Studi kepustakaan dimaknai sebagai rangkaian kegiatan riset yang dilakukan dengan pengumpulan sumber literatur, membaca, dan mengolah serta mengkaji literatur berdasarkan topik penelitian (Mirzaqon \& Purwoko, 2018). Pada peneltian ini digunakan 
sumber primer dan sekunder. Sumber primer yang bersal dari artikel hasil penelitian dan sumber sekunder dari buku, bahan ajar, dokumen, dst.

Prosedur yang dilakukan dalam riset ini meliputi: 1) pemilihan topik; 2) eksplorasi informasi; 3) menentukan fokus penelitian; 4) pengumpulan sumber data; 5) persiapan penyajian data; dan 6) penyusunan laporan (Mirzaqon \& Purwoko, 2018).

\section{HASIL DAN BAHASAN}

\section{a. Konsep Dasar Mindskills}

Mindskills merupakan keterampilan dasar konseling yang perlu dipahami dan dikuasai oleh konselor. Para ahli BK berusaha untuk mendefinisikan mindskills agar mudah diterima konselor profesional. Berikut ini adalah beberapa definisi mindskills yang dikemukakan oleh para ahli.

Jones (2005) mendefinisikan mindskills sebagai rangkaian tindakan sistematis yang dilakukan oleh konselor dalam proses konseling agar tujuan konseling dapat berjalan dengan sukses dan efektif. Tindakan yang sistematis dapat diciptakan ketika konselor mengoptimalkan fungsi kerja pikiran. Dengan kata lain, semakin konselor dapat memberdayakan dan mengontrol pikirannya maka akan berdampak pada pola komunikasi yang terarah dan perilaku yang bijaksana.

Joni (2008) menyebut mindskills dalam bahasa lain dengan sebutan mindcompetence. Mind-conpetence dipahami sebagai bentuk responsibel seorang konselor secara kontekstual yang bermuara pada kemampuan pemecahan masalah dalam konseling. Pernyataan tersebut sambung dengan pendapat Jones (2005) yang menyebutkan bahwa mindskills adalah keterampilan untuk monitoring dan refleksi pikiran yang berpengaruh pada pengambilan keputusan dalam pemecahan masalah.

Dawson (2008) juga menjelaskan mindskills dengan istilah yang lain sebagai keterampilan metakognisi. Metakognisi didefinisikan sebagai keterampilan berfikir tentang hal yang difikirkan (thinking of thinking). Metakognisi dapat dipahami sebagai seperangkat kompetensi yang saling berhubungan satu sama lain ketika seseorang belajar, berfikir kritis, reflektif, dan mengambil suatau keputusan.

Merujuk pada beberapa pendapat ahli, dapat ditarik sebuah simpulan bahwa mindskills merupakan keterampilan dalam mengelola pikiran dengan penuh kesadaran dan 
perhitungan sehingga berdampak pada munculnya pola fikir yang jernih, perasaan yang tepat, dan tindakan yang bijak dalam proses konseling.

\section{b. Komponen Mindskills}

Komponen mindskills terdiri dari enam komponen, yaitu: peraturan yang membantu, persepsi yang membantu, wicara diri yang membantu, penjelasan yang membantu, pengharapan yang membantu, dan citra visual yang membantu (Jones, 2003; Jones 2005, Mulawarman \& Antika, 2020). Pada dasarnya konselor telah menggunakan potensi fikirannya dalam proses konseling, namun tidak banyak yang mengoptimalkannya. Melalui mindskills konselor dilatih untuk menggunakan potensi fikirannya dengan kesadaran penuh agar semua yang keluar dari konselor hal yang positif dan membantu. Berikut ini akan dijelaskan setiap komponen mindskills yang membantu.

Peraturan yang membantu adalah aturan bersifat fleksibel yang diciptakan oleh dan untuk dirinya sendiri dengan memperhatikan keyakinan terhadap diri sendiri (Jones 2005, Mulawarman \& Antika, 2020). Peraturan tersebut akan berdampak pada kondisi emosi, tindakan, dan pengambilan sebuah keputusan. Peraturan tersebut nantinya akan memberikan alur, pola, dan sistematika perilaku/tindakan konselor.

Persepsi yang membantu merupakan bentuk fikiran konselor yang digunakan untuk memprediksi tingkahlaku oranglain atau lingkungan sekitar (Jones 2005, Mulawarman \& Antika, 2020). Persepsi yang membantu dapat diciptakan dengan adanya bukti yang mendukung dan rasional yang realistis. Bukti dan rasional tersebut membuat persepsi semakin presisi, proporsional, dan bertangungjawab.

Wicara diri (self-talk) yang membantu adalah proses komunikasi dengan diri sendiri (berbicara dengan diri sendiri) (Jones 2005, Mulawarman \& Antika, 2020). Wicara diri digunakan konselor untuk penguatan diri, refleksi, menilai, dan menemukan hal yang membantu dalam proses konseling. Wicara diri yang bersifat positif akan berdampak baik dalam mengelola fikiran, perasaan, dan tindakan.

Citra Visual yang membantu merupakan proses memvisualisasi/menggambarkan sebuah informasi dalam fikiran (Jones 2005, Mulawarman \& Antika, 2020). Melalui visualisasi informasi konselor mendapatkan informasi yang seolah jelas, mendalam, dan dapat membantu aktivitas konselor. Selain itu, dengan citra visual diperoleh kesadaran, 
menumbuhkan empati, meningkatkan pemahaman atas suatu kondisi/kejadian sehingga dapat merespons dengan tepat.

Penjelasan yang membantu adalah proses memberikan penjelasan/alasan atas apa yang difikirkan, dirasakan, dan dilakukan dengan tepat serta rasional (Jones 2005, Mulawarman \& Antika, 2020). Ketika konselor dapat memberikan alasan/rasional yang tepat tetang pemikiran, perasaan, dan tindakan maka semua tindakannya terukur dan dapat dipertanggungjawabkan. Dengan demikian, alasan yang membantu akan membantu konselor dalam meningkatkan kesadaran dan keyakinan dalam berfikir, berperasaan, dan bertindak.

Pengharapan yang membantu merupakan proses konselor memandang lingkungan, mengirimkan informasi dalam memori, dan membentuk perilaku (Jones 2005, Mulawarman \& Antika, 2020). Pengharapan yang positif membantu konselor dalam merencanakan dan mencapai tujuan tertentu. Pengharapan yang positif memiliki dampak terciptanya layanan konseling yang efektif.

\section{c. Konsep Dasar Konseling Realita}

Konseling realita memandang bahwa manusia digerakkan oleh lima kebutuhan dasar. Lima kebutuhan dasar yang dimaksud adalah kelangsungan hidup (survive), cinta dan rasa memiliki (love and belonging), kekuasaan dan prestasi (power and achievement), kebebasan (freedom), dan kesenangan (fun). Semua perilaku manusia mengarah pada upaya untuk memenuhi kebutuhan-kebutuhannya (Glasser, 1998). Lebih lanjut kelima kebutuhan dasar menurut sudut pandang konseling realita dijelaskan sebagai berikut.

Kebutuhan kelangsungan hidup sering disebut dengan kebutuhan fisik. Kebutuhan fisik ini bertempat di otak tua yang berlokasi di sebuah kelompok kecil struktur yang terklaster dalam puncak tulang belakang. Gen orang menginstruksikan otak tuanya untuk melaksanakan semua kegiatan yang menjaga kelangsungan hidup yang mendukung kesehatan dan reproduksi (Glasser, 1998; Prabawa, dkk., 2017).

Kebutuhan akan cinta dan rasa saling memiliki menuntut agar mereka menjaga cinta terus berlanjut selama hidupnya. Kebutuhan akan cinta dan rasa saling memiliki ini dapat dipenuhi oleh suami/istri, keluarga, kelompok, kelas, dan bahkan hewan kesayangan. Cinta dan pertemanan adalah jalan dua arah (saling menerima dan memberi). Kegagalan 
untuk memenuhi kebutuhan cinta dan rasa saling memiliki mungkin akan menjadi penyebab utama kesengsaraan manusia (Glasser, 1998; Prabawa, dkk., 2017).

Kebutuhan kekuasaan dan prestasi dapat dipuaskan oleh status, pengakuan, dan membuat orang lain mematuhi dirinya. Kebutuhan kekuasaan kebanyakan orang terpenuhi jika mereka didengarkan dan dihormati. Juga dimungkinkan untuk mendapatkan kekuasaan dengan mengupayakan kebaikan bersama (Glasser, 1998; Prabawa, dkk., 2017).

Kebutuhan akan kebebasan dipenuhi melalui kebebasan dalam memilih jalan atau cara menjalani kehidupannya. Orang perlu melakukan eksplorasi sesuka hatinya, mengekspresikan dirinya dengan bebas, dan berhubungan dengan siapapun yang mereka pilih (Glasser, 1998; Prabawa, dkk., 2017).

Kebutuhan akan kesenangan dan kegembiraan sama pentingnya dengan kebutuhankebutuhan lainnya. Kesenangan membebaskan dari kebosanan belajar dan menguatkan motivasi. Bahkan, di usia lanjut, belajar tanpa bermain sulit dilakukan. Berbagai kebutuhan yang kuat akan kesenangan mendukung semua hubungan manusia. Ketika ditanyai bagaimana dirinya bersenang-senang, Glasser mengatakan bahwa ia banyak tertawa (Glasser, 1998; Prabawa, dkk., 2017).

\section{d. Proses Perubahan Perilaku dalam Konseling Realita}

Konseling realita berpandangan bahwa fungsi otak adalah sebagai sistem kendali secara terus menerus, memantau perasaan untuk menentukan seberapa baik tindakan yang dilakukan dalam memenuhi setiap kebutuhan dasar (cinta dan kepemilikan, kekuasaan, kebebasan, kesenangan, dan kelangsungan hidup) (Glasser, 1998; Prabawa, dkk., 2017). Kondisi perasaan yang tidak nyaman, seperti: marah, cemas, takut, sedih, depresi merupakan sinyal yang menunjukkan bahwa ada kebutuhan yang belum terpenuhi dengan baik. Jauh sebelum orang mengetahui teori pilihan yang mengajarkan kebutuhan dasar, secara alamiah mereka menggunakan sinyal perasaan tersebut untuk mengetahui apakah kebutuhannya telah terpenuhi atau belum.

Sejak kecil manusia terbiasa untuk membangun kehidupan ideal yang diinginkan berdasarkan pengalaman menyenangkan, aktivitas yang menyenangkan, dan lingkungan yang bersahabat. Sebaliknya bukan untuk menyadari kebutuhan dasar dalam diri yang mesti dipenuhi. Gambaran hidup yang menyenangkan tersebut disebut oleh Glasser 
sebagai "quality world". Wubbolding (2011) mengatakan bahwa "keunikan merupakan pondasi dari quality world". Kebutuhan dasar manusia itu sifatnya umum, namun keinginan manusia sifatnya khusus dan unik antara individu satu dengan yang lain. Jika dianalogikan maka quality world menjadi tujuan destinasi dalam fikiran ketika seseorang naik mobil dan memulai perjalanan. Sebuah perjalanan unik yang membedakan perjalanan satu dengan lainnya dalam memenuhi lima kebutuhan dasarnya.

Burdenski \& Wubbolding (2011) menganalogikan bagaimana orang berperilaku dengan bagian dari mobil, dengan sebutan mobil perilaku total dalam gambar 1 .

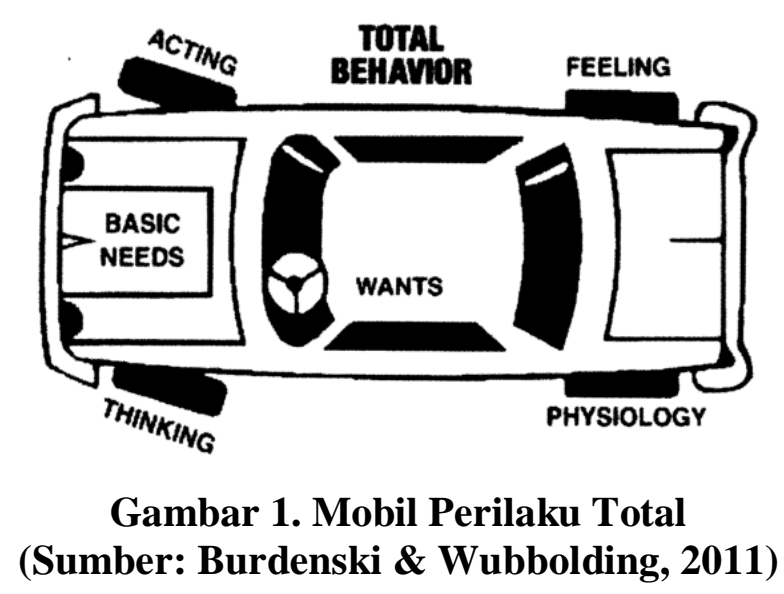

Total perilaku digambarkan menjadi empat roda mobil yang memiliki peran berbeda namun selalu bersinergi satu dengan yang lainnya. Mobil total perilaku ini melambangkan sebuah sistem motivasi manusia dan pentingnya setiap manusia bertanggungjawab atas semua dimensi perilakunya (bertindak, berfikir, merasakan, dan fisiologis). Dua roda depan mewakili bertindak dan berfikir menjadi komponen penting dalam perjalanan memenuhi kebutuhan. Dua roda belakang juga tidak kalah penting dalam perjalanan, perasaan dan kondisi fisiologis memberikan sinyal awal apakah kondisi mobil masih normal atau tidak normal dalam perjalanan (Burdenski \& Wubbolding, 2011).

Sommers-Flanagan (2004) menjelaskan fungsi mobil total perilaku secara keseluruhan sebagai sistem motivasi berperilaku. Menurut teori pilihan mesin mewakili kebutuhan dasar, sebab manusia ketika ingin memenuhi kebutuhan harus mensinergikan semua sistem secara keseluruhan. Ketika manusia memiliki tujuan "quality world" maka ia akan menyelaraskan antara kemudi dan kecepatan untuk segera sampai pada tujuan yang ingin dicapai. Seperti halnya, ketika pagi hari manusia akan beraktifitas untuk 
memenuhi yang telah diharapkan dan inginkan dengan penuh perhitungan dan penuh semangat dalam rangka memenuhi lima kebutuhan dasarnya.

Kedua roda depan mewakili tindakan dan pemikiran, dua bagian dari keseluruhan perilaku total yang di bawah kendali manusia. Manusia mengarahkan kedua roda tersebut ke arah tertentu untuk mendapatkan keinginannya. Roda depan melambangkan tindakan dan pemikiran dan roda belakang melambangkan perasaan dan fisiologis. Pada saat mengemudi, pengemudi memiliki kendali lebih atas dua roda depan untuk mengarahkan dari sisi ke sisi lain, sedangkan roda belakang akan mengikuti arah dari roda depan. Misalkan, ketika kemudi mobil diputar sedikit maka dalam jarak 15 meter pertama mobil tidak begitu terasa perubahannya. Berbeda jika kita tetap menjaga posisi kemudi tersebut dalam jarak $15 \mathrm{~km}$ maka kita akan berbelok secara dramatis. Perubahan sedikit demi sedikit akan bertambah besar seiring waktu. Sedikit penyesuaian pada roda akhirnya dapat mengubah total arah mobil (Burdenski \& Wubbolding, 2011). Berdasar analogi tersebut maka kita bisa ambil tarik makna bahwa perubahan sekecil apapun akan memiliki dampak yang besar dalam jangka waktu panjang. Lima kebutuhan dasar akan memberikan asupan tenaga dalam mesin dan intensitas kebutuhannya berbeda dari orang satu ke oranglain. Sesuai dengan matafora mobil, kekuatan dan ukuran tenaga setiap orang berbeda-beda bergantung pada lima kebutuhannya.

Meski terkadang rasanya kita memiliki sedikit kontrol terhadap pikiran kita, Glasser (1998) percaya bahwa pikiran layaknya seperti perilaku yang dapat dipilih. Berbeda dengan pikiran dan tindakannya yang secara langsung dikendalikan dan dipilih, perasaan dan fisiologis pada kapasitasnya merupakan pilihan yang sifatnya tidak langsung. Sekalipun fisiologis dan perasaan memiliki kapasitas yang berbeda namun pikiran dan tindakan tidak dapat dipisahkan darinya. Misalkan: Jika seseorang merasa penat dan suntuk dalam bekerja maka ia dapat pergi untuk film kesukaan di bioskop atau menikmati liburan di pegunungan.

Merujuk pada analogi yang telah dipaparkan maka ketika seseorang duduk di kursi kemudi, maka ia memiliki kendali penuh terhadap kehidupannya. Ia dapat memilih hal yang ingin ia lakukan, katakan, dan pikirkan dalam setiap situasi yang dihadapi. Ia dapat mengarahkan dan mensinergikan perilaku total untuk memenuhi kebutuhan dalam hidupnya. 


\section{e. Mindskills dalam Perspektif Perubahan Perilaku Konseling Realita}

Mindskills merupakan keterampilan untuk mengolah pikiran agar dapat mengendalikan pikiran, tindakan, perasaan (Jones 2005, Mulawarman \& Antika, 2020). Konsep tersebut memiliki gayut dengan konsep dasar perubahan perilaku dalam konseling Realita. Konseling realita berpandangan bahwa fungsi otak mengendalikan secara terus menerus, memantau perasaan untuk menentukan seberapa baik tindakan yang dilakukan dalam memenuhi setiap kebutuhan dasar (Glasser, 1998; Prabawa, dkk., 2017). Setiap orang memiliki keunikan dalam memenuhi setiap kebutuhannya, ada yang menggunakan cara yang bertanggungjawab, dihitung dengan matang, dan adapula sebaliknya memenuhi kebutuhannya dengan cara pintas tidak memperhitungkan konsekuensinya. Mindskills akan berperan untuk membantu dalam memperhitungkan cara yang lebih bertanggungjawab dalam memenuhi kebutuhan manusia melalui kelola pikiran.

Manusia memiliki kendali penuh terhadap kehidupannya, ia dapat mengarahkan apa yang menjadi keinginannya (wants) (Glasser, 1998; Burdenski \& Wubbolding, 2011; Prabawa, dkk., 2017). Keinginan tersebut tentu bukan hanya keinginan semata untuk memenuhi hasrat diri. Suatu hal yang terlihat baik, menyenangkan, memuaskan, indah di lingkungan sekitar, belum tentu berlaku baik untuk diri seseorang. Setiap orang memiliki kapasitas pemenuhan lima kebutuhan dasar yang berbeda-beda atau unik. Hendaknya manusia memiliki kesadaran dan memahami kebutuhan apa yang seharusnya menjadi prioritas untuk dipenuhi. Salah satu komponen mindskills ada yang disebut dengan pengharapan (Jones 2005, Mulawarman \& Antika, 2020). Pengharapan merupakan sebuah cita-cita yang ingin dicapai dengan memperhatikan potensi dalam diri. Melalui implementasi mindskills pengharapan tersebut keinginan (wants) dapat dikelola dengan realistis. Realistis yang dimaksud adalah dengan melakukan refleksi kebutuhan yang belum terpenuhi, menentukan prioritas kebutuhan, dan mengetahui potensi diri.

Ketika manusia memiliki keinginan yang akan dicapai, maka manusia memiliki gambaran yang jelas terhadap destinasinya. Wubbolding (2011) menyebut dengan quality world terhadap gambaran ideal destinasi yang akan dituju untuk memenuhi kebutuhan. Quality world memberikan semangat untuk segera meraih keinginan tersebut. Semakin menarik gambaran quality world maka semakin besar pula semangat untuk segera mencapai keinginan tersebut. Keindahan dan kemenarikan quality world tersebut dapat diciptakan di dalam pikiran setiap manusia. Salah satu komponen mindskills yang dapat 
membantu membentuk quality world di dalam pikiran manusia adalah citra visual. Citra visual merupakan kemampuan untuk mengolah informasi yang diterima menjadi sebuah gambaran visual yang nampak nyata untuk membantu memahami kondisi yang terjadi (Jones 2005, Mulawarman \& Antika, 2020). Dengan demikian, diperlukan citra visual yang positif untuk membentuk quality world yang lebih nyata, realistis, dan mereduksi visual yang negatif. Semakin sering manusia bercitra visual positif maka semakin indah dan menarik quality world yang digambarkan. Hal tersebut bermuara pada tingkat presisi dalam membentuk gambaran kebutuhan yang akan dipenuhi dan semangat untuk menuju destinasi keinginan yang akan dicapai.

Konseling realita menekankan bahwa perilaku manusia dapat dirubah melalui pengubahan pemikiran dan tindakan (Glasser, 1998; Burdenski \& Wubbolding, 2011; Prabawa, dkk., 2017). Manusia memiliki kontrol langsung terhadap tindakan dan pikirannya. Kondisi perasaan dan fisiologi manusia akan memiliki dampak hasil dari tindakan dan pemikiran. Ketika manusia bertindak tidak sesuai dengan quality world yang terjadi adalah muncul perasaan tidak nyaman bahkan kondisi fisiologis terganggu. Contohnya: Andi sedang sibuk mendapatkan pekerjaan, ia menjadi cemas, stress dan sering merasa sakit perut.

Tindakan manusia sangat berkait erat dengan pemikiran (Glasser, 1998; Burdenski \& Wubbolding, 2011; Prabawa, dkk., 2017). Pemikiran yang baik akan mengarahakan pada kondisi tindakan yang baik pula. Tindakan yang baik dapat dibentuk melalui pengelolaan pikiran. Misalkan ketika seseorang memiliki sifat perfectionis dan tindakan yang dilakukan ternyata tidak sesuai harapan maka yang terjadi perasaan kecewa. Dengan demikian perlu mengelola pemikiran melalui mindskills peraturan agar tindakan yang dilakukan lebih luwes, sesuai kondisi, dan realistis (Jones 2005, Mulawarman \& Antika, 2020). Hal tersebut akan berdampak pada kondisi perasaan yang lebih dapat menerima dan lapangdada.

Kondisi perasaan juga dapat dikontrol melalui mindskills wicara diri (Jones 2005, Mulawarman \& Antika, 2020). Kecemasan merupakan akibat dari tidak dapat dipenuhinya kebutuhan dengan baik. Maka manusia dapat kondisi perasaan tersebut dengan memberikan perhatian terhadap diri sendiri melalui wicara diri (self talk). Wicara diri bertujuan untuk menenangkan, memberi sugesti positif, dan untuk memotivasi diri sendiri. 
Pada ujungnya perasaan menjadi lebih tenang dan nyaman. Ketika perasaan nyaman dan tenang maka kondisi fisiologis manusia menjadi lebih stabil dan tidak bergejolak.

Konseling realita juga mengajarkan manusia untuk berperilaku yang bertanggungjawab (Glasser, 1998; Burdenski \& Wubbolding, 2011; Prabawa, dkk., 2017). Artinya bahwa setiap berpikir dan bertindak selalu dihitung dan dipertimbangkan secara matang konsekuensinya. Melalui mindskills penjelasan, setiap pikiran dan tindakan manusia selalu dapat dijelaskan secara rasional (Jones 2005, Mulawarman \& Antika, 2020). Oleh karenanya, mindskills penjelasan melatih manusia selalu bertanggungjawab sebelum mereka bertindak.

Setiap keinginan manusia harus mempertimbangkan kebutuhan dasar yang akan dipenuhi (Glasser, 1998; Burdenski \& Wubbolding, 2011; Prabawa, dkk., 2017). Tidak semua menusia memiliki kesadaran dan ketepatan dalam mengetahui kebutuhan yang benar-benar menjadi prioritas. Oleh karenanya perlu ada sebuah keterampilan yang melatih untuk memprediksi dengan presisi kebutuhan yang ingin dicapai. Salah satu komponen mindskills yang dapat membantu untuk belajar memprediksi adalah mindskills presepsi (Jones 2005, Mulawarman \& Antika, 2020). Melalui mindskills presepsi manusia diajarkan untuk tidak terburu-buru dan hati-hati dalam menyimpulkan ataupun memutuskan keinginan yang sesuai kebutuhan.

\section{KESIMPULAN}

Pengubahan perilaku dalam konseling realita akan berjalan dengan efektif jika diiringi dengan implementasi mindskills. Mindskills membantu untuk mengontrol pemikiran dan tindakan yang merupakan komponen utama dalam pengubahan perilaku konseling realita. Melalui pengendalian pikiran dan tindakan, maka secara tidak langsung dapat mengkondisikan perasaan dan fisiologis. Mindskills pengharapan dapat digunakan untuk mengelola keinginan (wants) agar lebih realistis. Mindskills citra visual digunakan untuk menggambarkan kebutuhan yang akan dipenuhi secara presisi. Mindskills peraturan membantu agar tindakan yang dilakukan lebih luwes, sesuai kondisi, dan realistis. Mindskills wicara diri membantu mengkondisikan perasaan dan fisiologis. Mindskills penjelasan membantu pikiran dan tindakan secara rasional. Mindskills presepsi membantu untuk tidak terburu-buru dan hati-hati dalam menyimpulkan ataupun memutuskan keinginan yang sesuai kebutuhan. 


\section{DAFTAR RUJUKAN}

Antika, E. R. (2017). Internalisasi Mind-Skills Mahasiswa BK dalam Praktik Keterampilan Dasar Komunikasi melalui Strategi Supervisi Terbimbing. (Bahan ajar tidak diterbitkan). Pascasarjana BK UM, Malang, Indonesia.

Azmi. (2015). Pengembangan Panduan Pelatihan Mind Skills Dalam Konseling Dengan Model Experiential Learning Untuk Mahasiswa Bimbingan Dan Konseling Universitas Negeri Malang. (Skripsi tidak dipublikasikan). Universitas Negeri Malang, Malang, Indonesia.

Burdenski, T. \& Wubbolding, R. (2011). Extending Reality Therapy with Focusing: A Humanistic Road for the Choice Theory Total Behavior Car. International Journal of Choice Theory and Reality Therapy: An On-Line Journal. Vol XXXI, (1):14-30.

Dawson, T.L. (2008). Metacognition and Learning in Adulthood. England: Northampon.

Egan, G. (2010). The Skilled Helper: A Problem Management and Opportunity Development Approach to Helping. United State of America: Thomson.

Glasser, W. (1998). Choice Theory: A New Psychology of Personal Freedom. New York: HarperCollins Publishers.

Hidayah, N. (2009). Process-Audit dalam Penyelenggaraan Pendidikan Akademik S1 Bimbingan dan Konseling. (Disertasi tidak dipublikasikan). PPS Universitas Negeri Malang, Malang, Indonesia.

Hidayah, N. (2012). Penerapan Model Pembelajaran Berbasis Pengalaman untuk Mengembangkan Mind Competence Calon Konselor. (Laporan penelitian tidak dipublikasikan). Lembaga Penelitian dan Pengabdian kepada Masyarakat UM, Malang, Indonesia.

Jones, R.N. (2003). Basic Counselling Skills: A Helper's Manual. London: Sage Publication.

Jones, R.N. (2005). Introduction to Counselling Skills: Text and Activities. London: Sage Publications.

Joni, T.R. (2008). Penajaman Keterampilan Konseling. (Naskah tidak dipublikasikan) Program Pascasarjana Universitas Negeri Malang, Malang, Indonesia.

Kemdikbud RI. (2016). Panduan Operasional Penyelenggaraan Bimbingan Dan Konseling Sekolah Menengah Atas (SMA). Jakarta: Kemdikbud.

Mirzaqon, T. A. \& Purwoko, B. (2018). Studi Kepustakaan Mengenai Landasan Teori Dan Praktik Konseling Expressive Writing. Jurnal BK Unesa, 8 (1), 1-8.

Mulawarman, dkk. (2017). Motif-motif Pribadi dan Mind-Skills pada Mahasiswa Jurusan BK FIP UNNES: Studi Mixed-Methods. (Laporan penelitian tidak dipublikasikan). Lembaga Penelitian dan Pengabdian kepada Masyarakat UNNES, Semarang, Indonesia.

Mulawarman \& Antika. (2020). Mindskills: Konsep dan Aplikasinya dalam Praktik Konseling. Jakarta: Kencana.

Prabawa, A.F. \& Antika, E. (2015). Krisis Identitas Bimbingan dan Konseling Indonesia. Paper dipresesntasikan pada Seminar Nasional Bimbingan Dan Konseling "Profesi Bk Di Era Masyarakat Ekonomi Asean (MEA)", UMM, Malang, 13 Desember 2015 (hlm. 116-123). Malang: UMM.

Prabawa, A.F., Ramli, M., Fauzan, L. (2017). Pengembangan Website Cybercounseling Pendekatan Reakita untuk Meningkatkan Keterbukaan Diri (Self-Disclosure) Siswa. Jurnal Kajian Bimbingan dan Konseling, 2 (1), 1-11. 
Prayitno \& Amti, E. (2015). Dasar-Dasar Bimbingan Dan Konseling, Jakarta: Rineka Cipta.

Purwaningrum, R. 2013. Keterampilan Berpikir (Mind-Skills) dalam Konseling. (Bahan ajar tidak diterbitkan). Pascasarjana BK UM, Malang, Indonesia.

Radjah, C. (2012). Metakognisi Konselor dalam Kegiatan Layanan Konseling di Sekolah. (Desertasi tidak dipublikasikan) PPS Universitas Negeri Malang, Malang, Indonesia.

Rigg, L. (1941). Is Counseling the Heart of Guidance Program?. The High School Journal, 24 (6), 253-255.

Sommers-Flanagan, J., \& Sommers-Flanagan, R. (2004). Counseling and psychotherapy theories in context and practice: Skills, strategies, and techniques. New York: Wiley.

Wubbolding, R. E. (2011). Reality therapy: Theories of psychotherapy series. Washington, DC: American Psychological Association. 